www.jmscr.igmpublication.org

Impact Factor 5.84

Index Copernicus Value: 83.27

ISSN (e)-2347-176x ISSN (p) 2455-0450

crossref DOI: _https://dx.doi.org/10.18535/jmscr/v5i4.56

\title{
Prevalence of physical and genital injuries in female victim of rape: A Three Year Institution Based Cross-Sectional Study
}

\section{Authors \\ Dr Shalender Kumar ${ }^{1}$, Dr Rajendra Singh ${ }^{2}$, Dr O.P. Saini ${ }^{3}$, Dr P.K. Saini ${ }^{4}$ Dr Manoj Garg ${ }^{5}$, Dr Sanjeev Buri ${ }^{6}$}

${ }^{1}$ Assistant Professor, Dept. of Forensic Medicine \& Toxicology, S.P Medical College, Bikaner, Rajasthan Email: drsksaharan79@gmail.com

${ }^{2,4,6}$ Assistant Professor, Dept. of Forensic Medicine \& Toxicology, S.P Medical College, Bikaner, Rajasthan

${ }^{3}$ Associate Professor, Dept of Forensic Medicine \& Toxicology, S.P Medical College, Bikaner, Rajasthan

${ }^{5}$ Senior Demonstrator, Dept. of Forensic Medicine \& Toxicology, S.P Medical College, Bikaner, Rajasthan

\begin{abstract}
Sexual violence is a significant cause of physical and psychological harm and suffering for women and children. Sexual violence constitutes the most barbaric crimes against the women. Sexual violence on female subject is a global health and human right issue. The problem has legal as well as health related bearing. The medical findings during examination of a female victim of sexual assault case are invariably minimal or absent. The purpose of forensic examination in a rape case is to search for physical signs \& search, collection, preservation of all physical evidences and to treat the victim for physical, genital injuries, venereal disease \& lessening of psychological harm. The pattern of injuries in a rape case also has a forensic value in view that these injuries are linked to the outcome of legal proceedings.

Keywords: - sexual assault, rape, hymen, global health issue, genital and physical injuries.
\end{abstract}

\section{Introduction}

Rape is an assault by a person involving sexual intercourse with another person without that person's consent. ${ }^{1}$ The term rape is sometimes used interchangeably with the term sexual assault. ${ }^{2}$ Rape is the fourth most common crime against women in India. ${ }^{3}$ According to the National Crime Records Bureau of India (NCRBI) 2015 annual report, 34,651 rape cases were reported across India in 2015; and Madhya Pradesh has the highest number of rape-reports among Indian states. ${ }^{4}$ The pandemicity of rape is due to the very nature of this issue itself, e.g. rape can be easily alleged, difficult to prove and more difficult to disprove. The law enforcement agencies usually face difficult to prove such allegations. Hence, it needs to understand the veracity of 'rape-charges' and the 'alleging party' as well. ${ }^{5}$

The prevalence of genital and physical injuries are calculated from injury frequency, can be described as the proportion of females with an occurrence of any injury at anogenital region, on cheeks, lips, neck, breast, lower abdomen, inner aspect of thigh and other parts of body especially bruises and scratches may be found around the mouth and throat produced while preventing her from calling for help. Bruising of lips and even tearing of the inner mucosal surface may be found due to blows 
or rough handling. Injuries are found around wrists and arms where the man seized her, on back specially shoulders and buttocks from pressure on the ground, on the thigh and buttock from struggle to achieve intercourse, on breast by rough handling, true bite marks and love bite marks may be usually found on the breast specially around nipples, on face, neck, shoulders, lower abdomen and on thighs. Marks of general violence and genital injuries are likely found about one third to one fifth cases respectively. Absence of general physical injuries can be there due to submission of the victim due to fear, the force used or resistance offered is insufficient to produce injuries, due to delayed bruising, due to delayed reporting for medical examination. Injury to labia minora is not common but finger nail scratches may be present particularly on labia minora and inner aspect of upper third part of thigh. Swelling and tenderness of labia minora indicates recent sexual activity. The character and extent of injuries varies in different cases depending upon the nature of the hymen, disproportion between penis and vagina, extent of penetration and amount of force used. Tearing usually occurs posteriorly at the sites between 4 \& 8 o'clock position but most frequently in midline of hymen. Several hymenal lacerations indicate first sexual intercourse.

Aims and objectives: - To establish a link between history given by victim and prevalence of injuries.

\section{Material and Methods}

A cross-sectional study was conducted in the Department of Forensic Medicine and Toxicology, S. P. Medical College, Bikaner, on 104 numbers of alleged rape cases reported to our department during the period from January 2014 up to December 2016. Cases were referred from investigating police authorities for evidentiary examination.

\section{Inclusion Criteria}

All cases registered under Section 376 I.P.C. by the police, with or without sections of other offences
The information regarding victim's age, marital status, status of hymen (intact, freshly torn \& old healed torn), general physical injuries and genital injuries were collected from all examined rape victims and recorded in a pre- tested proforma. In this study the only technique used for detection of general physical injuries as well as genital injuries is unaided eyes due to lack of facilities with staining techniques and colposcopy techniques. The emphasis is made to elicit the all injuries by taking history of incidence as well as medical examination carefully.

\section{Observations}

During the study period (01 January 2014 to 31 December 2016) 104 cases were brought in Department of Forensic Medicine and Toxicology, S. P. Medical College for examination of rape, out of which 93 cases were examined. Remaining 11 cases were not examined due to refusal for examination.

The age range of the cases reported was from 2 years to 55 years. 56 cases $(53.84 \%)$ out of 104 cases were in the age range of 11-20 years and 65 cases $(62.5 \%)$ are unmarried women. Physical injuries were found in 21 cases $(20.19 \%)$ whereas genital injuries were present in only 08 cases (7.69\%). Hymen was found old healed torn in 84 cases $(80.76 \%)$, freshly torn in 08 cases and intact in 01 case.

\section{Table -1}

\begin{tabular}{|l|c|c|}
\hline $\begin{array}{l}\text { No. Of case } \\
\text { reported }\end{array}$ & $\begin{array}{c}\text { No. Of case } \\
\text { examined }\end{array}$ & $\begin{array}{c}\text { No. Of cases refused } \\
\text { for examination }\end{array}$ \\
\hline 104 & 93 & 11 \\
\hline
\end{tabular}

Table-2: Age wise distribution of cases

\begin{tabular}{|l|c|}
\hline Age groups & No. Of cases \\
\hline $0-10$ yrs & $03(02.88 \%)$ \\
\hline $11-20$ yrs & $56(53.84 \%)$ \\
\hline $21-30$ yrs & $31(29.82 \%)$ \\
\hline $31-40$ yrs & $05(04.81 \%)$ \\
\hline $41-50$ yrs & $07(06.73 \%)$ \\
\hline $51-60$ yrs & $02(01.92 \%)$ \\
\hline Above 60 yrs & $00(00.00 \%)$ \\
\hline Total cases & $104(100 \%)$ \\
\hline
\end{tabular}


Table-3: Year \& Marital status wise distribution of sex assault cases

\begin{tabular}{|l|c|c|c|}
\hline \multirow{2}{*}{ Year } & \multicolumn{3}{|c|}{ No of cases } \\
\cline { 2 - 4 } & Married & Un-married & Total \\
\hline 2014 & 16 & 15 & 31 \\
\hline 2015 & 15 & 25 & 40 \\
\hline 2016 & 08 & 25 & 33 \\
\hline Total & $39(37.50 \%)$ & $65(62.5 \%)$ & $104(100 \%)$ \\
\hline
\end{tabular}

Table -4: Distribution of cases according physical injuries and genital injuries

\begin{tabular}{|l|c|}
\hline Trait & No of cases \\
\hline Physical injuries present & $21(22.5 \%)$ \\
\hline Genital injuries present & $08(8.6 \%)$ \\
\hline
\end{tabular}

Table-5: Distribution of cases according status of hymen

\begin{tabular}{|l|c|}
\hline Status of hymen & No. Of cases \\
\hline Intact & $01(01.08)$ \\
\hline Fresh torn & $08(8.60 \%)$ \\
\hline Old healed torn & $84(90.32 \%)$ \\
\hline Total cases & $93(100 \%)$ \\
\hline
\end{tabular}

\section{Discussion}

In our study, more than three quarters of victims of rape were in second or third decade of their life and $62.5 \%$ were unmarried, is in accordance with the findings of other authors. ${ }^{7,8,9}$ La Harpe $\mathrm{R}$ et al. a study done in 2012, found majority of rapevictims are aged between 15 and 30 years. $^{6}$ Palmer CM et al. recorded $73 \%$ of rape-victims reported were aged under 30 years and only $4 \%$ were over 50 years. ${ }^{7}$ Some studies from Bangladesh and Pakistan have detected around $34 \%$ to $64 \%$ of the victims are between $10-19$ years of age. ${ }^{8,9}$ This higher prevalence among younger age group may be due to many factors, e.g. sexually vulnerable age, consensual sexual habits, can be easily preyed by the deceiving partners due to their openness to the liberal lifestyle, and often their heightened ambitions may lead to sexual exploitation. ${ }^{5}$

In our study general physical injuries and genital injuries are present in $22.5 \%$ and $8.6 \%$ respectively which are in accordance to other authors. Some other studies detected extra-genital and genital injuries ranging from $15 \%-46 \%$ and $7 \%-22 \%$ respectively. ${ }^{8,10,11}$ In our study, in more than $90 \%$ cases hymen was old healed torn and only in $8.6 \%$ cases hymen was fresh torn. Reason being- delayed reporting, passive attitude of the police to register a case of rape, fake allegations of rape, delay may due to the victim's or her parent's dilemma as there is potential fear of retaliation from the offender's family, or the fear of social embarrassment and humiliation. It's an unfortunate social condition in India, where the victim of rape is usually seen in an evil eye.

\section{Conclusions}

As technologies and examination techniques have improved, it reflects a growing ability by examiners to detect general physical as well as genital injuries. Some injuries are not detected due to delayed reporting for medical examination by victim. The trends of early reporting are increasing for medical examination due to increased awareness regarding sexual violence. Most common sites of general physical injuries are on wrist, neck, breast, lower abdomen and inner aspect of thigh. Most common sites for genital injuries are hymen, posterior fourchette, labia minora and fossa navicularis.

\section{References}

1. Aggarwal Anil. Textbook of Forensic Medicine and Toxicology, Avichal Publishing Company $1^{\text {st }}$ edition,2014;440

2. Hedge. The Trauma of Sexual Assault Treatment, Prevention and Practice. In: Petrak J, Barbara, editors. Chichester: John Wiley \& Sons; 2003. p. 2. ISBN 9780470851388

3. Kumar, Radha (1993). The History of Doing: An Account of Women's Rights and Feminism in India. Zubaan. p. 128. ISBN 978-8185107769

4. Crime in India 2015 Statistics: Crime against Women. National Crime Records Bureau. $63^{\text {rd }}$ edi.page.150. Available at: http://ncrb.gov.in.

5. Ambika Prasad Patra et al. Victimology of alleged rape cases: A three year institution 
based cross- sectional study, Indian Journal of Forensic and Community Medicine, 2015;2( 4): 203 - 213

6. La Harpe R, Vlastos AT. Sexual assaults in Geneva between 2006 and 2010. [Article in German]. Arch Kriminol 2012;229(3-4):117-25.

7. Grossin C, Sibille I, Lorin de la, Grandmaison G, Banasr A, Brion F, Durigon M. Analysis of 418 cases of sexual assault. Forensic Sci Int 2003; 131(2-3):125- 30. 31

8. Palmer CM, McNulty AM, D' Este C, Donovan B. Genital injuries in women reporting sexual assault. Sex Health. 2004;1(1):55-9

9. Hassan Q, Bashir MZ, Mujahid M, Munawar AZ, Aslam M, Marri MZ. Medico-legal assessment of sexual assault victims in Lahore. J Pak Med Assoc 2007;57(11):539-42

10. Islam MN. Retrospective study of alleged rape victims attended at Forensic Medicine Department of Dhaka Medical College, Bangladesh. Leg Med 2003;5(1):351-3

11. Grossin C, Sibille I, Lorin de la, Grandmaison G, Banasr A, Brion F, Durigon M. Analysis of 418 cases of sexual assault. Forensic Sci Int 2003; 131(2-3):125- 30.

12. Santos JC, Neves A, Rodrigues M, Ferrão P. Victims of sexual offences: medicolegal examinations in emergency settings. J Clin Forensic Med 2006; 13(6- 8):300-3. 